\title{
Lichenometric dating: a commentary, in the light of some recent statistical studies
}

\author{
Tom Bradwell \\ British Geological Survey, Murchison House, Edinburgh, UK
}

\begin{abstract}
This commentary article discusses the relative merits of new mathematical approaches to lichenometry. It highlights their strong reliance on complex statistics; their user unfriendliness; and their occasional mistreatment of existing lichenometric techniques. The article proposes that the success of lichenometric dating over the past 50 years has stemmed from its relative simplicity, transparency, and general field applicability. It concludes that any new techniques which ignore these principles are likely to be unjustified, unsuitable to the user community and inappropriate for the subject matter. Furthermore, the article raises a more general philosophical question: can statistical complexity and high precision in a 'geobotanical' dating technique, fraught with high degrees of environmental variability and in-built uncertainty, ever be scientifically valid?
\end{abstract}

\section{Introduction}

Lichenometric dating has come a long way since its first use in the 1930s. Proposed as a relative dating technique by Knut Faegri (1934) and developed by Roland Beschel (1950, 1958, 1961, etc.), lichenometric dating has now been employed in over 600 studies worldwide and on all 7 continents. (See recent reviews by Noller and Locke 2001; Solomina and Calkin 2003; Muller 2006; Bradwell and Armstrong 2007; Benedict 2009). Various different methodologies and data collection techniques have been adopted - these range from measuring the single or several largest lichens on a surface to measuring whole populations of several thousand lichen thalli (Table 1). Measurement parameters also vary. The long axis, short axis, average diameter, the mean diameter of a number of lichens, the modal frequency of lichen sizes, and the percentage of lichen cover have all been used as metrics to estimate surface age. All of these sampling strategies have marked effects on the construction of lichenometric dating curves, the reported lichen 'growth' rate, and consequently the lichenometric age and precision of the surface being dated.

Lichenometry started out as a botanical science - field based in essence, primarily the domain of the ecologist or geographer. As its use as a dating technique became more established in the 1960s and 70s, lichens were measured more often by 
geomorphologists and geologists eager to know the age of recent landforms, especially in high latitude and alpine settings. In the past decade, however, several papers have pushed lichenometry further towards the statistical sciences. Data collected in the field is now subjected to increasingly complex statistical procedures back in the office. In the past 3 years, 2 groups have presented lichen data using new and different statistical approaches: (1) The GEV (Generalized Extreme Value) group [Naveau et al. 2005, 2007; Cooley et al. 2006; Jomelli et al. 2007, 2008] and (2) The $\mathrm{U}^{2}$ group [Orwin et al. 2008].

The GEV group aim to determine the age of a surface by modelling the lichen population distribution using a Bayesian treatment of Generalized Extreme Value (GEV) distribution theory. The authors go on to claim that each lichenometric surface is characterised in time by varying the GEV location and scale parameter functions, and is characterised in space by fixing the GEV shape parameter (Naveau et al. 2005). The whole process involves several complex steps, following collection of the field data, including: (1) generation of a statistical function considered to be a "growth curve”; (2) application of a Bayesian model; (3) many iterations using a Monte Carlo Markov Chain procedure to obtain parametric convergence; (4) computation of an expected 'empirical' distribution for each parameter; and finally (5) calculation of 'surface-age' and derivation of confidence intervals. In a recent assessment study of lichenometric dating techniques, Jomelli et al. (2007) find their GEV technique to be the best performing and most accurate method. The GEV group have repeated their statistical approach and their arguments several times in a number of recent similar publications (i.e. Naveau et al. 2007; Rabatel et al. 2007; Jomelli et al. 2007).

The second new approach is not a dating technique per se but a way to distinguish between lichen populations with different size-frequency distributions. The authors use the $\mathrm{U}^{2}$ statistic to group lichen populations and, after numerous statistical steps (e.g. observation ranking, cluster analysis and similarity matrices), to assign relative ages to recent glacial deposits and highlight complex depositional histories (Orwin et al. 2008).

Both new lichenometric approaches are novel and interesting but will probably be of limited use and applicability to the wider community. Essentially this is because they 
are over-complicated and opaque to the non-statistician user. Unfortunately, both techniques also contain different flawed assumptions and inaccuracies. These are discussed within this article.

\section{Lichenometry as a dating technique}

Arguably, the beauty of lichenometry as a dating tool is its simplicity. It provides clear, powerful, quantitative results in a relatively quick, non-destructive and transparent way. It is particularly well suited to decoding Late Holocene glacial histories and has been used most often, and most successfully, in high latitude and alpine settings. In short, it has been demonstrated by many workers that a survey of largest-lichen diameters or lichen size-frequency distributions across recently deglaciated terrain will yield a good impression of the age of glacial landforms, whilst in the field. The size of the largest lichens acts as a good relative guide to the age of surfaces; which can be converted to absolute ages if a site-specific calibrated dating curve is available. It is this geobotanical phenomenon that was first noticed by Faegri and utilised by Beschel, and subsequently by many other workers in a wide range of settings. In its simplest form, lichenometry works well and can yield clear and meaningful results with very few intermediate steps or a priori assumptions. It is somewhat regrettable therefore that, in recent years, lichenometry has become removed from its humble origins and has started to lean too heavily on complex statistical approaches. It is particularly regrettable when these statistical approaches have not been shown to be appropriate to the lichenometric technique or to result in greater dating accuracy.

\section{Existing lichenometric techniques}

There are really only 4 different techniques in lichenometric dating:

1. The original approach of Beschel, often called the 'traditional approach' has been used to great effect many times since the 1950s. Beschel proposed that finding and measuring the largest lichen on a surface "growing under optimal environmental conditions" will result in the closest age-estimation (Beschel 1961: 1045). Consequently, this single largest lichen (LL) approach uses only the largest noncompeting lichen of one species growing on an entire surface to derive a lichenometric age. The mean of the largest 5 lichens (5LL) on a surface was developed in the 1970s as a modification of the LL approach primarily to avoid 
110 reliance on a single, potentially anomalous, lichen thallus. Others have chosen to use

11110 or more 'largest lichens', however several studies have shown that neither

112 accuracy nor precision is improved by measuring more than the 5 largest lichens on a

113 surface (e.g. Matthews 1975, 1994; Innes 1984). Some workers have chosen to use the

114 LL or 5LL technique within a representative sample area (from 25-500 $\mathrm{m}^{2}$ ), when a

115 whole-surface search is not practical. However, dating curves constructed using this

116 fixed-area approach cannot be directly compared to those constructed using the LL on

117 an entire surface, owing to the different sizes of the search areas (Innes 1983b, 1984).

118 It is true that searching only part of a surface goes against the main assumption of the

119 original LL technique, however as long as the same technique is used in the

120 construction of the dating curve and for dating purposes the technique can be justified

121 in most cases.

122 2. The fixed-area largest lichen (FALL) approach has been used, chiefly by Bull 123 and co-workers, to ascertain the age and event history of diachronous surfaces.

124 Essentially a development of the LL approach, this technique measures the single 125 largest thallus of one species within a unit sample area. These sample areas, typically 126 boulders, usually average $\sim 1 \mathrm{~m}^{2}$. The measurements from one surface (c. 100-500) are 127 pooled to allow statistical treatment and age projections. It is important to state that 128 the FALL technique was specifically designed to study rockfall and talus 129 accumulations where the age of the deposit may not be uniform (McCarroll 1993; 130 Bull et al. 1994). Unlike the previous approaches, this technique is based on the 131 assumption that lichen populations have a normal distribution of thallus sizes, and that 132 the mean thallus size increases with surface age. Using the FALL technique, Bull and 133 Brandon (1998) recorded an accuracy of $+/-10$ years on rockfall deposits up to 500 134 years old in New Zealand.

135 3. The size-frequency approach (SF) was originally devised to identify multiple 136 populations or anomalous, inherited or pre-existing, thalli growing on a single surface 137 (Benedict 1967, 1985); but has since been used successfully as a relative and absolute 138 dating technique (e.g. Caseldine 1991; Benedict 1999, 2009; Bradwell 2004; Bradwell 139 et al. 2006). The SF approach has also been used to assess substrate stability, snow140 kill frequency, lichen population structure and micro-environmental tolerance. It 141 differs from the other techniques in that the operator records the long axis of all thalli 142 of a single species growing within a representative sub-sample of the surface. Sample 143 areas vary, but normally cover at least $25-50 \mathrm{~m}^{2}$, and may include between 200 to 
1445000 thalli. For best results, sample sizes of 1000 or more lichens are recommended

145 (Benedict 2009). Whilst on smaller surfaces, every lichen should be measured.

146 4. The lichen cover approach (LC) is based on the assumption that the percentage 147 of a rock surface covered by a single species of lichen will increase with time.

148 Estimates of lichen cover are not common in lichenometric dating studies, although

149 several authors have reported success in constructing relative chronologies using this 150 technique (e.g. Birkeland 1973; Locke et al. 1979; Grab et al. 2005). The LC 151 technique is the most subjective of the 4 lichenometric dating approaches (Innes 152 1986a) and consequently is usually only used when the other 3 techniques are 153 impractical. However, recent advances in digital image analysis may allow more 154 quantitative lichen-cover studies to be performed (McCarthy and Zaniewski 2001).

156 All other lichenometric techniques are essentially modifications of one of these four 157 methods. Most 'new' techniques merely use different statistical treatments of field 158 data collected using one of the 4 techniques outlined above (i.e. LL/5LL, FALL, SF, 159 LC). A powerful development of the LL technique was devised by Vanessa 160 Winchester in the 1980s. She used multiple lichen species to derive several site161 specific dating curves which, when used in combination, reduced uncertainty and 162 improved accuracy (Winchester 1984). Using this multi-species approach, Winchester 163 (1988) claimed precision of 1-2 years on stone monuments spanning the last 800 years 164 in England. Surprisingly, few have adopted this technique to date recent glacial 165 landforms - possibly owing to the lack of species diversity and the lack of control 166 surfaces in many glacial environments.

168 Only the FALL approach makes assumptions about the size-frequency distribution of 169 lichens on a surface. The SF approach measures, and therefore quantifies the precise 170 size-frequency distribution of any given lichen population. The mathematical nature 171 of the SF distribution on a specific surface, whether truncated log-normal, skewed, 172 Poisson or otherwise, can only be determined from careful measurement of usually 173 several hundred or more thalli. It is also worth stating that there is currently no 174 consensus on the idealised nature of crustose lichen SF distributions (e.g. McCarthy 175 1999). However, in young developmental populations, typical of those on Little Ice 176 Age moraines, where space restriction is not a factor, statistical normality will 
commonly apply (e.g. Innes 1983b, 1986b; Haines-Young 1988; McKinzey et al. 2004).

\section{Recent statistical treatments of lichenometric data}

Processing lichenometric data and deriving absolute calendar ages for publication, with confidence intervals or error bars, is highly dependent on 2 things: the strength and validity of the dating-curve calibration; and the statistical treatment of the measurement data. Varying either of these 2 factors will produce widely differing results. The GEV group claim to build on a detailed statistical treatment published by McCarroll (1993, 1994). However, this lichenometric approach was principally devised to investigate geomorphic activity in multi-event deposits. Rather than using the size-frequency approach, which is best suited for dating single-event surfaces, McCarroll chose to modify the largest lichen approach to examine the age-frequency of avalanche boulders. As McCarroll (1993: 529) states in his study aims: "it is not the frequency distribution of lichens of different size that is of interest, but the frequency distribution of boulders of different age”. This study, and those of Bull and co-workers (1994, 1996, 1998) - who examined earthquake-generated rockfalls have succeeded in using lichens to identify and date multi- and single-event deposits. But the GEV group go on to presume that all lichen-dating studies make the same assumptions made by McCarroll and Bull; whilst forgetting (or not recognising) that these authors were dealing with a specific modification of the lichenometric technique.

The GEV group criticise previous lichenometric techniques on the basis that "they assume that the largest lichens follow a Gaussian distribution” (Jomelli et al. 2007: 137). However this is a misconception, and their statement may be based on a misunderstanding. The largest lichen in any population is by definition an extreme, hence why the largest lichens are far less numerous in any population, as found in many previous studies. But the "extreme” nature of the largest thalli does not require the statistical complexity of Generalized Extreme Value theory to calculate a lichenometric dating curve (or simply an age-size function) based on largest lichens. A calibrated age-size dating curve is simply an empirical relationship between the largest thallus (or mean of the 5 largest), assumed to be the oldest, and the surface age 
211 of the feature, where the independent variable (x-axis) is time. There is no assumption

212 of normal distribution in this procedure - Gaussian or otherwise. In its purest form,

213 lichen dating curves can tell us, by interpolation, how old we should expect a certain-

214 sized lichen to be. It is arguably this simplicity which has made the technique so

215 useful to so many for so long.

217 The presentation of lichenometric dates has yet to be standardised, particularly regarding the calculation of confidence intervals. The GEV group claim (e.g. Cooley et al. 2006; Jomelli et al. 2007) that this as an inherent weakness in existing lichenometric approaches, and they attempt to devalue previous work which does not present the associated mathematical uncertainties. Jomelli et al. (2007: 140) criticize those studies which derive confidence intervals that "lack a mathematical foundation". Instead they propose the use of their highly complex statistical approach (a Bayesian treatment of Generalized Extreme Value theory) in the perceived pursuit of greater precision and to calculate stronger mathematical confidence intervals (Cooley et al. 2006; Naveau et al. 2006; Jomelli et al. 2007). They fail to recognise that uncertainties have been expressed quite succinctly and precisely in many 'traditional' lichenometric studies (e.g. see Table 1). For dating curves constructed using the LL or 5LL, 2 standard deviations are preferred (95\% confidence limits). The interpolated ages can be presented with the associated standard error, derived in the normal way,

231 using (a) the lichen diameter, (b) the relevant calibration points, and (c) the value of the curve fitted through the calibration points at the relevant intersection. Any calibrated-age dating technique, such as lichenometry, will always be subject to the precision uncertainties of the field measurements combined with the construction of the calibration curve. These can be expressed and, in many cases, are incorporated into the derived lichenometric ages. If a new technique to derive mathematical uncertainty implies greater confidence than the original data warrants, regardless of its complexity, the technique risks serving no purpose. This is surely a major criticism of the new methodology proposed by the GEV group.

The SF technique makes use of a simple class-size statistical treatment in order to

242 firstly determine the composition of the lichen population, whether it is unimodal or 243 not, and secondly uses linear regression to determine the age of the population 244 measured against a SF distribution 'calibration curve'. This technique has had 
considerable success both as a relative and an absolute dating technique, and is more statistically robust than the LL or 5LL techniques because of the large number of measurements which make up a single age-determination (Benedict 1985, 1999, 2009; Locke et al. 1979; Innes 1983b, 1986b; Caseldine 1991; Cook-Talbot 1991; Bradwell 2004; Bradwell et al. 2006). It is not dependent on assumptions of statistical normality within lichen populations, although several studies have shown skewed normal distributions to be typical on young surfaces (e.g. Innes 1986b; Haines Young 1988; Bradwell 2004; McKinzey et al. 2004). The SF approach is the least criticised by the GEV group in their assessment study of lichenometric dating techniques (Jomelli et al. 2007). However, they fail to see any advantages of the SF approach over their newly proposed GEV technique; and in conclusion Jomelli et al. (2007) omit the SF approach as a valid alternative to their own more statistically complex, and somewhat confusing, Bayesian GEV approach. The reason for this omission is not altogether clear, however it may be due to the construction of their experiment and a misunderstanding of the SF technique. Jomelli et al. (2007) could not perform the SF technique in one of their two test areas because they chose tombstones with small surface areas (typically $<2 \mathrm{~m}^{2}$ ). In the second test area, glacier forelands in the Bolivian Andes (Rabatel et al. 2006), the SF measurement data appear to have been collected unconventionally - possibly erroneously. Jomelli et al. (2007: 137) state that they measured at least 300 lichens "randomly selected” within a fixed area of $50 \mathrm{~m}^{2}$ "1 lichen per block”. This is not the normal SF approach - which measures all thalli within a fixed area - and therefore their results cannot be compared with the conventional SF approach used by others (e.g. Benedict 1985, 1999, 2009; Innes 1983b, 1986b; Bradwell 2004). This confused methodology, a mix of the SF and FALL techniques, may explain the apparent success of the GEV approach, as tested by Jomelli et al. (2007), over other more traditional lichenometric techniques such as the SF approach. Failure to recognise this flaw, along with the propagation of other false assumptions previously mentioned, seriously compromises the assessment study of Jomelli et al. (2007). Consequently, advocation and adoption of the GEV method as the "most reliable" lichenometric dating technique (Jomelli et al. 2007: 131) is The complex statistical treatment proposed by Orwin et al. (2008) is not a dating 278 method, but a technique which helps to identify lichen-colonized surfaces with similar 
279 histories. Orwin et al. (2008) propose the use of the $U^{2}$ statistic (Watson, 1961) to 280 quantify the closeness of fit between any two lichen size-frequency distributions. The $281 \mathrm{U}^{2}$ function has been used by statisticians for over 4 decades, but never before applied 282 to lichenometry. Orwin et al's methodology is built around and based on the SF 283 approach, and in fact uses the same dataset as the lichenometric study conducted by 284 McKinzey et al. (2004).

286 The $\mathrm{U}^{2}$ technique may prove useful when examining lichen populations on multi287 event surfaces. However, it is statistically cumbersome involving numerous steps, 288 (observation ranking, cluster analysis and similarity matrices) whilst seeming to offer 289 little in return. In many of the lichen populations from SE Iceland (Orwin et al. 2008; 290 Fig. 3) visual inspection and simple statistics (i.e. mode, falling limb gradient or 291 central tendency) easily describe their similarity or difference. Hence, the use of the $292 \mathrm{U}^{2}$ statistic to distinguish between unimodal populations with markedly different SF 293 gradients seems unnecessary and overcomplicated (e.g. HJ8708 \& HJ8704 in Orwin 294 et al. 2008; Fig. 3). The technique's ability to distinguish between complex or 295 polymodal populations does represent a methodological advance. However, simple 296 visual inspection can again prevent the inclusion of composite or polymodal 297 populations in SF dating studies. This is important as older polymodal lichen 298 populations cannot be dated with SF age-gradient curves (sensu Bradwell 2004) as 299 they usually contain inherited thalli or multiple natality and mortality events (Innes 300 1983b, 1986b; McCarthy 1999). Simply stated, the use of complex $U^{2}$ statistics 301 merely groups lichen populations with similar size-frequency distributions; it cannot 302 decode moraine chronologies or the associated environmental conditions in any more 303 detail than the lichen SF data itself. The use of this technique in "augmenting 304 lichenometric surface dating” is suggested by Orwin et al. (2008: 151). However, it 305 may offer little in uncomplicated, recessional moraine sequences; and it remains to be 306 seen how the complex $\mathrm{U}^{2}$ statistics once generated can be applied to extract 307 environmental information.

\section{Some ecological uncertainties}

310 Philosophically, it is hard to defend the use of high precision, highly complex 311 statistics (such as those proposed by the GEV group) to solve what is essentially a 312 simple problem: How can the size of lichens growing on a surface best inform us of 
313 its age? Owing to the nature of the subject matter, uncertainty will always be high

314 and hence dating precision will, in reality, always be low. Numerous ecological

315 factors, central to the establishment and growth of the lichen thallus, determine this

316 statement. A review of these factors, although probably timely, is far beyond the

317 scope of this short article. However, it goes without saying that environmental

318 conditions can vary greatly from site to site and even within sites. This can lead to

319 problems when trying to calibrate or standardise field procedures, for instance when

320 constructing a lichenometric dating curve. Uncertainties still surround the different

321 growth rate of non-competing crustose lichens on surfaces with different aspect, slope

322 angle, lithology, macro- and microclimate. Some of these topics remain largely

323 unstudied, or are still being explored (e.g. Armstrong 1993, 2002, 2006, etc.). When

324 combined with added uncertainties surrounding competition between thalli and

325 between species (Armstrong and Welch 2007); differences in fungal (hypothallus)

326 growth relative to algal (areolae) growth (Armstrong and Bradwell 2001); the impact

327 and timing of mortality events (Loso and Doak 2006); and the importance of

328 biological niches within certain environments (McCarthy 1999) - the range of factors

329 likely to influence the growth rates of lichens becomes far greater. Even the exact

330 nature of the growth curve in the most commonly used species in lichenometric dating

331 (R. geographicum), although found to be non-linear over time, is still debated and in

332 need of further study (cf. Proctor 1983; Matthews 1994; Bradwell and Armstrong

333 2007). Careful research has shown that lichen growth is strongly controlled by

334 moisture availability (Armstrong 1976, 2006; Benedict 1990). As a consequence,

335 micro-environmental factors such as slope inclination (horizontal or vertical), surface

336 orientation (to prevailing winds), surface texture and lithology may play an equally

337 important role in determining growth rates alongside regional climatic conditions.

338 Until the time when these key growth rate factors have been fully examined, and

339 preferably quantified, in-built uncertainty will always surround the derivation of

340 lichenometric dates even when local dating curves are used and field-measurement

341 errors are minimised.

\section{Summary}

345 This article attempts to dispel some of the current myths surrounding the statistical

346 treatment of lichenometric data. Recent studies using complex statistics - most 
notably by the GEV group - are attempting to overcomplicate what is a simple scientific technique. Many workers have successfully dated old surfaces using traditional lichenometric methods (see Table 1). In the North Atlantic region, the technique has enjoyed over 50 years of success and in this time has received several modifications and tweaks since the first studies by Roland Beschel. Importantly though, the long-established practice of comparing lichen sizes in the field with a carefully calibrated dating curve has proven effective for many workers in many countries over many years. So is it really time to adopt a new, considerably more complex, considerably less transparent technique, when the old one has not been found wanting? For this reason, advocation of highly complex statistical techniques, such as the GEV approach, in pursuit of greater reliability or improved accuracy over and above existing lichenometric techniques - seems premature and probably unjustified. These novel uses of statistics, whether to examine lichen populations growing on "similar historied surfaces" (Orwin et al. 2008), or to model uncertainties within idealised distributions (Naveau et al. 2007), leave the average potential user baffled by their complexity and inapplicability. Clearly, a good scientific technique is one which is only as complex as the subject matter warrants. In the case of lichenometry - a simple, user-friendly, field technique - the use of complex statistics is hard to support (e.g. Cooley et al. 2006; Naveau et al. 2007; Jomelli et al. 2007;

366 Orwin et al. 2008) - particularly given the natural complexity and variability inherent 367 within the lichen growing environment.

Whilst uncertainty still surrounds fundamental questions regarding lichen ecology, lichenometric dating will never be an exact science. In the meantime, any attempt to make it so should be viewed with caution and healthy scepticism. The lichen-dating community still awaits consensus on key questions relating to: the exact shape of the

373 lichen growth curve; the typical size-frequency distribution for populations of 374 different age; the effects of species competition; and the effects of temperature, precipitation and seasonality changes on lichen growth rates over many years. Lastly, on a more philosophical note (and maybe a suitable subtitle for this article), all this begs the question: can statistical complexity in pursuit of high precision ever be scientifically justified in a poorly understood 'geobotanical' dating technique? 


\section{Acknowledgements}

382 I thank Richard Armstrong for discussions on lichen growth and lichen dating over 383 the past 10 years. Communications with Richard have significantly shaped my 384 thoughts on a wide range of lichen-related issues. Constructive and balanced reviews 385 by Danny McCarroll, Olga Solomina and Wibjörn Karlén are gratefully acknowledged; although the views expressed in this paper are those of the author

Dr Tom Bradwell, British Geological Survey, Murchison House, West Mains Road, Edinburgh, EH9 3LA, UK

Email: tbrad@bgs.ac.uk

\section{References}

394 Anda, E. Orheim, O. and Mangerud, J., 1985: Late Holocene glacier variations and climate at Jan Mayen. Polar Research, 3: 129-145.

André, M.F., 1986: Dating slope deposits and estimating rates of rock wall retreat in

Armstrong, R.A., 1973: Seasonal growth and growth rate-colony size relationships in six species of saxicolous lichens. New Phytologist, 72: 1023-1030.

Armstrong, R.A., 1976: The influence of the frequency of wetting and drying on the radial growth of three saxicolous lichens in the field. New Phytologist, 77: 719-724.

Armstrong, R.A., 1983: Growth curve of the lichen Rhizocarcarpon geographicum. New Phytologist, 73: 913-918.

Armstrong, R.A., 1993: The growth of six saxicolous lichens transplanted to lime-rich and lime-poor substrates in south Gwynedd, Wales. Symbiosis, 15: 257-267.

Armstrong, R.A., 2002: The effect of rock surface aspect on growth, size structure and competition in the lichen Rhizocarpon geographicum. Environmental and Experimental Botany, 48: 187-194.

Armstrong, R.A., 2006: Seasonal growth of the crustose lichen Rhizocarpon geographicum (L.) DC. in South Gwynedd, Wales. Symbiosis, 41: 97-102.

Armstrong, R.A. and Bradwell, T., 2001: Variation in hypothallus width and the growth of the lichen Rhizocarpon geographicum (L.) DC. Symbiosis, 30: 317-328.

Armstrong, R.A. and Welch, AR., 2007: Competition in lichen communities. Symbiosis 43: 1-12. 
Bakke, J., Dahl, S.O., Paasche, O., Lovlie, R. and Nesje, A., 2005: Glacier fluctuations, equilibrium-line altitudes and palaeoclimate in Lyngen, northern Norway, during the Lateglacial and Holocene.The Holocene. 2005: 15: 518-540

Ballantyne, C.K., 1990: The Holocene glacial history of Lyngshalvøya, northern Norway: chronology and climatic implications. Boreas, 19: 93-117.

Benedict, J.B., 1967: Recent glacial history of an Alpine area in the Colorado Front Range, USA. 1: Establishing a lichen growth curve. Journal of Glaciology, 6: 817832.

Benedict, J.B., 1985: Arapaho Pass: Glacial geology and archaeology at the crest of the Colorado Front Range. Center for Mountain Archaeology, Ward, Colorado, Research Reports, 3: 1-197.

Benedict, J.B., 1990: Experiments on lichen growth. I. Seasonal patterns and environmental controls. Arctic and Alpine Research, 22: 244-254.

Benedict, J.B., 1999: Effects of changing climate on game-animal and human use of the Colorado High Country (U.S.A) since 1000BC. Arctic, Antarctic and Alpine Research, 31: 1-15.

Benedict, J.B., 2009: Lichenometry for Archeologists: a Review. American Antiquity,74: $\mathrm{x}-\mathrm{xx}$.

Beschel, R.E., 1950: Flechten als Altersmassstab rezenter Moränen. Zeitschrift fur Gletscherkunde und Glazialgeologie, 1: 152-161.

Beschel, R.E., 1958: Lichenometrical studies in West Greenland. Arctic, 11: 254

Beschel, R.E., 1961: Dating rock surfaces by lichen growth and its application to glaciology and physiography (lichenometry). In: G. O. Raasch (ed.): Geology of the Arctic (Proceeding of the First International Symposium on Arctic Geology), Vol. 2. University of Toronto Press, Toronto: 1044-1062.

Beschel, R.E., 1973: Lichens as a measure of the age of recent moraines. Arctic and Alpine Research, 5: 303-309. (Translation, by William Barr, of Beschel, R.E. 1950).

Bickerton, R.W. and Matthews, J.A., 1992: On the accuracy of lichenometric dates: An assessment based on the 'Little Ice Age' moraine sequence at Nigardsbreen, southern Norway. The Holocene, 2: 227-237.

Birkeland, P.W., 1973: The use of relative dating methods in a stratigraphic study of rock glacier deposits, Mt Sopris, Colorado. Arctic and Alpine Research, 5: 401-416.

Bradwell, T., 2004: Lichenometric dating in southeast Iceland: the size-frequency approach. Geografiska Annaler, 86A: 31-41. 
Bradwell, T., Dugmore, D.J. and Sugden, D.E., 2006: The Little Ice Age glacier maximum in Iceland and the North Atlantic Oscillation: evidence from Lambatungnajökull, southeast Iceland. Boreas, 35: 61-80.

Bradwell, T. and Armstrong, R.A., 2007: Growth rates of Rhizocarpon geographicum: a review with new data from Iceland. Journal of Quaternary Science, 22: 311-320.

Broadbent, N.D. and Berqvist, K.I., 1986: Lichenometric chronology and archaeological features on raised beaches: preliminary results from the Swedish north Bothnian coastal region. Arctic and Alpine Research, 18: 297-306.

Bull, W.B., 1996: Dating San Andreas fault earthquakes with lichenometry. Geology, 24: 111-114.

Bull, W.B. and Brandon, M.T., 1998: Lichen dating of earthquake-generated regional rockfall events, Southern Alps, New Zealand. Geological Society of America Bulletin, 110: 60-84.

Bull, W.B., King, J., Kong, F., Moutoux, T. and Phillips, W.M., 1994: Lichen dating of coseismic landslide hazards in alpine mountains. Geomorphology, 10: 253-264.

Caseldine, C.J., 1991: Lichenometric dating, lichen population studies and Holocene glacial history in Tröllaskagi, Northern Iceland. In: Maizels, J.K. and Caseldine, C.J. (Eds) Environmental Change in Iceland: Past and Present: 219-233. Kluwer, Dordrecht.

Caseldine, C. and Baker, A., 1998: Frequency distribution of Rhizocarpon geographicum s.l., modeling, and climate variation in Tröllaskagi, northern Iceland. Arctic and Alpine Research, 30: 175-183.

Cook-Talbot, J.D., 1991: Sorted circles, relative-age dating and palaeoenvironmental reconstruction in an alpine periglacial environment, eastern Jotunheimen, Norway: lichenometric and weathering-based approaches. The Holocene, 1: 128-141.

Cooley, D., Naveau, P., Jomelli, V., Rabatel, A. and Grancher, D., 2006: A Bayesian hierarchical extreme value model for lichenometry. Environmetrics, 17: 555-574.

Evans. D.J.A., Butcher, C. and Kirthisingha, A.V., 1994: Neoglaciation and an early Little Ice Age in western Norway: lichenometric evidence from the Sandane area. The Holocene, 4: 278-289.

Evans, D.J.A., Archer, S. and Wilson, D.J.H., 1999: A comparison of the lichenometric and Schmidt hammer dating techniques based on data from the proglacial areas of some Icelandic glaciers. Quaternary Science Reviews, 18: 13-41.

Faegri, K., 1934: Über die Längenvariationen einiger Gletscher des Jostedalsbre und die dadurch bedingten Pflanzensukzessionen. Bergens Museums Aarbog, 1993: 137142. 
Gordon, J.E. and Sharp, M., 1983: Lichenometry in dating recent glacial landforms and deposits, southeast Iceland. Boreas, 12: 191-200.

Grab, S. van Zyl, C. and Mulder, N., 2005: Controls on basalt terrace formation in the eastern Lesotho Highlands. Geomorphology, 67: 473-485.

Gudmundsson, H.J., 1998: Holocene glacier fluctuations of the Eiríksjökull ice cap, west central Iceland. Jökull, 46: 17-28.

Haines-Young, R.H., 1983: Size variation of Rhizocarpon on moraine slopes in southern Norway. Arctic and Alpine Research, 15: 295-305.

Haines-Young, R.H., 1988: Size-frequency and size-density relationships in populations from the Rhizocarpon sub-genus Cern. on moraine slopes in southern Norway. Journal of Biogeography, 15: 863-878.

Hooker, T.N., 1980: Factors affecting the growth of Antarctic crustose lichens. British Antarctic Survey Bulletin, 50: 1-19.

Innes, J.L., 1983a: The development of lichenometric dating curves for Highland Scotland. Transactions of the Royal Society of Edinburgh Earth Sciences, 74: 23-32.

Innes, J.L., 1983b: Size-frequency distributions as a lichenometric technique: an assessment. Arctic and Alpine Research, 15: 285-294.

Innes, J.L., 1984: The optimal sample size in lichenometric studies. Arctic and Alpine Research, 16: 233-244.

Innes, J.L., 1985: Lichenometry. Progress in Physical Geography, 9: 187-254.

Innes, J.L., 1986a: The use of percentage cover measurements in lichenometric dating. Arctic and Alpine Research, 18: 209-216.

Innes, J.L., 1986b: The size-frequency distributions of the lichens Sporastatia testudinea and Rhizocarpon alpicola through time at Storbreen, south-west Norway. Journal of Biogeography, 13: 283-291.

Innes, J.L., 1988: The use of lichens in dating. In: M. Galun (ed.) CRC Handbook of Lichenology. Volume III. CRC Press, Inc., Boca Raton: 75-91.

Jomelli, V., Grancher, D., Naveau, P., Cooley, D. and Brunstein, D., 2007:

Assessment study of lichenometric methods for dating surfaces. Geomorphology, 86: 131-143.

Jomelli, V., Grancher, D., Brunstein, D. and Solomina, O., 2008: Recalibration of the yellow Rhizocarpon growth curve in the Cordillera Blanca (Peru) and implications for LIA chronology. Geomorphology, 93: 201-212. 
Jonasson, C., Kot, M. and Kotarba, A. 1991: Lichenometrical studies and dating of debris flow deposits in the High Tatra Mountains, Poland. Geografiska Annaler, 73(A): 141-146.

Kirkbride, M.P. and Dugmore, A.J., 2001: Can lichenometry be used to date the 'Little Ice Age' glacial maximum in Iceland? Climatic Change, 48: 151-167.

Kugelmann, O., 1991: Dating recent glacier advances in the SvarfaðardalurSkiðadalur area of northern Iceland by means of a new lichen curve. In: Maizels, J.K. and Caseldine, C. (Eds.) Environmental Change in Iceland: Past and Present: 203217. Kluwer Academic Publishers.

Locke, W.W., Andrews, J.T. and Webber, P.J., 1979. A manual for lichenometry. British Geomorphological Research Group Technical Bulletin 26.

Loso, M.G. and Doak, D.F., 2006: The biology behind lichenometric dating curves. Oecologia, 147: 223-229.

Macklin, M.G., Rumsby, B.T. and Heap, T., 1992: Flood alluviation and entrenchment: Holocene valley floor development and transformation in the British Uplands. Geological Society of America Bulletin, 104: 631-643.

Matthews J.A., 1975: Experiments on the reproducibility and reliability of lichenometric dates, Storbreen gletschervorfeld, Jotunheimen, Norway. Norsk Geografisk Tidsskrift, 29: 97-109.

Matthews, J.A., 1994: Lichenometric dating: A review with particular reference to 'Little Ice Age' moraines in southern Norway. In: Beck, C. (ed.) Dating in Surface Contexts. New Mexico University Press: 185-212.

Matthews J.A., 2005: 'Little Ice Age' glacier variations in Jotunheimen, southern Norway: a study in regionally controlled lichenometric dating of recessional moraines with implications for climate change and lichen growth rates. The Holocene 15: 1-19.

McCarroll, D., 1993: Modelling late-Holocene snow-avalanche activity; incorporating a new approach to lichenometry. Earth Surface Processes and Landforms, 18: 527-539.

McCarroll, D., 1994: A new approach to lichenometry: dating single-age and diachronous surfaces. The Holocene, 22: 383-396.

McCarroll, D. Shakesby, R.A. and Matthews, J.A., 2001: Enhanced rockfall activity during the Little Ice Age: Further lichenometric evidence from a Norwegian talus. Permafrost and Periglacial Processes, 12: 157-164.

McCarthy, D.P., 1999: A biological basis for lichenometry? Journal of Biogeography, 26: 379-386. 
McCarthy, D.P. and Zaniewski, K., 2001: Digital analysis of lichen cover: a technique for use in lichenometry and lichenology. Arctic, Antarctic, and Alpine Research, 33: 107-113.

McKinzey, K., Orwin, J. and Bradwell, T., 2004: Re-dating the moraines at Heinabergsjokull and Skalafellsjokull using different lichenometric methods: implications for the timing of the Icelandic Little Ice Age maximum. Geografiska Annaler, 86A: 319-336.

Müller, G., 2006: Lichenometry and environmental history. Environmental History 11: 604-609.

Naveau, P., Nogaja, M., Ammann, C., Yiou, P., Cooley, D. and Jomelli, V., 2005: Statistical methods for the analysis of Geophysical extreme events. Comptes Rendus de l'Académie des Sciences, 337: 1013-1022.

Naveau, P., Jomelli, V., Cooley, D. and Rabatel, A., 2007: Modeling uncertainties in lichenometry studies with an application: the Tropical Andes (Charquini Glacier in Bolivia). Arctic, Antarctic, and Alpine Research, 39: 277-285.

Noller J.S. and Locke W.W., 2001: Lichenometry. In Quaternary Geochronology: Methods and Applications, Noller, JS et al. (eds). American Geophysical Union: Washington DC; 261-272.

Orwin, J.F., McKinzey, K.M., Stephens, M.A. and Dugmore, A.J., 2008: Identifying moraine surfaces with similar histories using lichen size distributions and the $\mathrm{U}^{2}$ statistic, southeast Iceland. Geografiska Annaler, 90A: 151-164.

Principato, S.M., 2008: Geomorphic evidence for Holocene glacial advances and sea level fluctuations on eastern Vestfirdir, northwest Iceland. Boreas, 37: 132-145.

Proctor M.C.F., 1983: Sizes and growth-rates of thalli of the lichen Rhizocarpon geographicum on the moraines of the Glacier de Valsorey, Valais, Switzerland. The Lichenologist 15: 249-261.

Rabatel, A., Jomelli, V., Francou, B., Naveau, P. and Grancher, D., 2005: Dating the Little Ice Age in the tropics from the moraines of Charquini Glaciers (Andes of Bolivia, 16 S). Comptes Rendus de l'Académie des Sciences, 337: 1311-1322.

Rapp, A. and Nyberg, R., 1981: Alpine debris flows in Northern Scandinavia. Geografiska Annaler, 63: 183-196.

Solomina, O. and Calkin, P.E., 2003: Lichenometry as applied to moraines in Alaska, USA and Kamchatka, Russia. Arctic, Antarctic, and Alpine Research, 35: 129-143.

Thompson, A. and Jones, A., 1986: Rates and causes of proglacial river terrace formation in southwest Iceland: an application of lichenometric dating techniques. Boreas, 15: 231-246.

Watson, G.S., 1961: Goodness-of-fit tests on a circle. Biometrika, 48: 109-114. 
666 Winchester, V., 1984: A proposal for a new approach to lichenometry. British

667 Geomorphological Research Group, Technical Bulletin, 33: 3-20.

668

669 Winchester, V., 1988: An assessment of lichenometry as a method for dating recent

670 stone movements in two stone circles in Cumbria and Oxfordshire. Botanical Journal

671 of the Linnean Society, 96: 57-68.

672

673 Winchester ,V. and Chaujar R.K., 2002: Lichenomtric dating of slope movements,

674 Nant Ffrancon, North Wales. Geomorphology 47: 61-74.

675

676 Winkler S., Matthews J.A., Shakesby R.A. and Dresser P.Q., 2003: Glacier variations

677 in Breheimen, southern Norway: dating Little Ice Age moraine sequences at seven

678 low-altitude glaciers. Journal of Quaternary Science, 18: 359-413.

679 
Table 1. A cross-section of lichenometric dating studies conducted in northern Europe since 1980.

\begin{tabular}{|c|c|c|c|c|c|c|c|c|c|}
\hline author(s) & $\begin{array}{l}\text { date }^{1} \\
(\mathrm{AD})\end{array}$ & location & lichen species $^{2}$ & technique $^{3}$ & $\begin{array}{lr}\text { lichen } & \text { no. } \\
\text { dimension } & \text { r }\end{array}$ & $\begin{array}{l}\text { 10. of lichens } \\
\text { recorded }^{4}\end{array}$ & $\begin{array}{l}\text { survey area } \\
\left(\mathrm{m}^{2}\right)\end{array}$ & $\begin{array}{l}\text { calibration } \\
\text { surfaces }^{6}\end{array}$ & $\begin{array}{l}\text { uncertainty } \\
\text { expressed }\end{array}$ \\
\hline Rapp and Nyberg & 1981 & Abisko Mtns, Sweden & R. geographicum agg. & LL & long axis & 1 & variable & ex. curve & no \\
\hline Innes & 1983 & Scottish Highlands & $R$. section Rhizocarpon & $\mathrm{LL}$ & long axis & 1 & entire & gravestones & no \\
\hline \multirow[t]{2}{*}{ Gordon and Sharp } & 1983 & Breiðamerkurjökull and & R. geographicum agg. & $5 \mathrm{LL}$ & short axis & 5 & 1500 & moraines & yes \\
\hline & & Skálafellsjökull, Iceland & R. geographicum agg. & $5 \mathrm{LL}$ & long axis & 5 & 150 & moraines & yes \\
\hline Anda et al. & 1985 & Jan Mayen & R. geographicum & LL & long axis & 1 & entire & moraines & no \\
\hline Thompson and Jones & 1986 & Öræfi, SE Iceland & R. geographicum agg. & $5 \mathrm{LL}$ & short axis & 5 & entire & moraines & yes \\
\hline Broadbent and Bergqvist & 1986 & Bothnia coast, Sweden & Rhizocarpon subgenus & $\mathrm{LL}, \mathrm{SF}$ & long axis & 203 & entire & raised beaches & yes \\
\hline Andre & 1986 & NW Spitsbergen & R. subgen. Rhizocarpon & LL & long axis & 1 & variable & $\mathrm{n} / \mathrm{a}$ & $\mathrm{n} / \mathrm{a}^{7}$ \\
\hline Winchester & 1988 & Cumbria, England & R. geographicum subsp. & $\mathrm{LL}$ & long axis & 1 & entire & gravestones & no \\
\hline Ballantyne & 1990 & Lyngshalvoya, Norway & Rhizocarpon subgenus & 5LL, SF & long axis & $100-400$ & variable & gravestones & no \\
\hline Kugelmann & 1991 & Skiðadalur, Iceland & R. geographicum agg. & LL & long axis & 1 & entire & gravestones & yes \\
\hline Cook-Talbot & 1991 & Jotunheimen, Norway & R. geographicum agg. & 5LL, SF & long axis & 300 & variable & ex. curve & no \\
\hline Jonasson et al. & 1991 & High Tatra Mtns, Poland & R. geographicum & & & & & & \\
\hline Caseldine & 1991 & Tröllaskagi, Iceland & R. geographicum s.l. & $\mathrm{SF}$ & long axis & 1000 & variable & debris flows & $\mathrm{n} / \mathrm{a}^{7}$ \\
\hline Macklin et al. & 1992 & North Pennines, England & $\begin{array}{l}\text { R. geographicum and } \\
\text { Huilia tubercolosa }\end{array}$ & 3LL & long axis & 3 & variable & $\begin{array}{l}\text { gravestones, } \\
\text { bridges }\end{array}$ & no \\
\hline Bickerton and Matthews & 1993 & Jostedalsbreen, Norway & Rhizocarpon subgenus & $\mathrm{LL}, 5 \mathrm{LL}$ & long axis & 5 & c. 430 & ex. curve & yes \\
\hline McCarroll & 1993 & Jostedalen, W Norway & R. geographicum agg. & FALL & long axis & 100 & $<2$ & ex. curve & yes \\
\hline Evans et al. & 1994 & Sandane, W Norway & $R$. section Rhizocarpon & 5LL & long axis & 5 & 20 & ex. curve & no \\
\hline Gudmundsson & 1998 & Eiriksjökull, Iceland & R. geographicum & $5 \mathrm{LL}$ & short axis & 5 & entire & ex.curve & no \\
\hline Evans et al. & 1999 & Vatnajökull, Iceland & R. geographicum s.l. & $5 \mathrm{LL}$ & long axis & 5 & entire & m, sh, br, g & no \\
\hline McCarroll et al. & 2001 & Hurrungane, W Norway & genus Rhizocarpon & FALL & long axes & 100 & $<2$ & ex. curve & yes \\
\hline Kirkbride and Dugmore & 2001 & Eyjafjallajökull, Iceland & R. geographicum & $\mathrm{LL}, 5 \mathrm{LL}, \mathrm{SF}$ & long axis & $>250$ & $50-100$ & $\mathrm{~m}, \mathrm{fd}$ & no \\
\hline Winchester and Chaujar & 2002 & North Wales & R. geographicum subsp. & SF & long axis & $100-500$ & variable & gravestones & no \\
\hline Winkler et al. & 2003 & Breheimen, Norway & Rhizocarpon subgenus & LL, 5LL & long axis & 5 & variable & ex. curve & no \\
\hline Bradwell & 2004 & SE Iceland & R. section Rhizocarpon & $\mathrm{LL}, \mathrm{SF}$ & long axis & $>250$ & $30-100$ & $\mathrm{~m}, \mathrm{rf}, \mathrm{lf}, \mathrm{fd}$ & no \\
\hline Matthews & 2005 & Jotunheimen, Norway & Rhizocarpon subgenus & LL, 5LL & long axis & 5 & 200 & moraines & no \\
\hline Bakke et al. & 2005 & Lyngen, Norway & R. geographicum & $5 \mathrm{LL}$ & long axis & 5 & 30 & ex. curve & no \\
\hline Bradwell & 2006 & $\begin{array}{c}\text { Lambatungnajökull, } \\
\text { Iceland }\end{array}$ & R. section Rhizocarpon & LL, SF & long axis & $>250$ & $30-100$ & m, rf, lf, fd & yes \\
\hline Principato & 2008 & Vestfirdir, Iceland & R. geographicum & $5 \mathrm{LL}$ & mean diameter & 5 & entire & ex. curve & no \\
\hline
\end{tabular}




\section{Notes}

1 - year of publication, not necessarily year of lichenometric survey.

2 - species, or taxonomic classification, as stated in publication.

3 - principal dating technique(s) used: LL (largest lichen); 3LL (3 largest lichens); 5LL (5 largest lichens); FALL (fixed-area largest lichen); SF (size-frequency distribution); see text for more details on different techniques.

4 - total number of lichens measured per surface in order to derive numerical age ( 1 = only largest-lichen used $)$

5 - average search area of lichenometric survey per surface, where stated. 'Entire' indicates the whole surface was searched. For FALL surveys, search areas are not recorded; a nominal value of $<2 \mathrm{~m}^{2}$ has been ascribed.

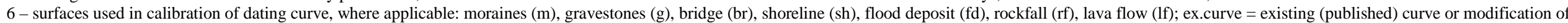

existing curve used to derive ages.

7 - relative ages only; uncertainty not applicable. 